\title{
SEKOLAH RUMAH RAMAH ANAK SEBAGAI SOLUSI PENDIDIKAN JARAK JAUH DI TENGAH PANDEMI COVID-19
}

\author{
Zulfa Ilma Nuriana ${ }^{1}$, Alifarose Syahda Zahra ${ }^{2}$ \\ IAIN Tulungagung, Universitas Kahuripan Kediri, Indonesia ${ }^{1,2}$ \\ nuriana633@gmail.com ${ }^{1}$, alifarose@kahuripan.ac.id ${ }^{2}$
}

\begin{abstract}
Covid-19 pandemic has a major impact on the world of education. Around $24.9 \%$ of students experience anxiety due to the Covid-19 Pandemic. Face-to-face education has also shifted to the Distance Education (PJJ) system. This shift is what worries parents because their children experience difficulties in self-regulation and understanding the material. Therefore, the researcher tried to provide a solution to this problem through this research. This research was qualitative. The method used was a literature study, interviews, and elementary school students' observations in Tulungagung and Blitar regencies. This study's results were that researchers recommend Child-Friendly Home Schools to the community, especially parents, because it was effectively applied in the learning process during the Covid-19 Pandemic.
\end{abstract}

Keyword: Education, Schools, the Covid-19 Pandemic

\begin{abstract}
ABSTRAK
Pandemi Covid-19 berdampak besar pada dunia pendidikan.Sekitar 24,9\% siswa mengalami kecemasan karena Pandemi Covid-19. Pendidikan tatap muka pun beralih dengan sistem Pendidikan Jarak Jauh (PJJ).Peralihan inilah yang dikhawatirkan orang tua karena anak-anknya mengalami kesulitan dalam self-regulation dan memahami materi. Oleh karena itu, peneliti berupaya untuk memberikan solusi dari permasalahan ini melalui penelitian ini. Penelitian ini adalah penelitian kualitatif. Metode yang digunakan adalah studi literatur, wawancara dan observasi ke siswa siswi Sekolah Dasar Kabupaten Tulungagung dan Blitar. Hasil dari penelitian ini adalah peneliti merekomendasikan Sekolah Rumah Ramah Anak kepada masyarakat khususnya orang tua karena efektif diterapkan dalam proses pembelajaran di masa Pandemi Covid-19.
\end{abstract}

Kata Kunci: Pandemi Covid-19, Pendidikan, Sekolah

\section{PENDAHULUAN}

Dunia digemparkan oleh coronavirus. Coronavirus dapat menyebabkan penyakit pada hewan atau manusia. Ada beberapa jenis coronavirus yang diketahui. Jenis-jenis tersebut menyebabkan infeksi saluran nafas pada manusia, mulai dari batuk pilek hingga yang lebih serius seperti Middle East Respiratory Syndrome (MERS) dan Severe Acute Respiratory Syndrome (SARS).Lantas Coronavirus jenis yang baru ditemukan menyebabkan penyakit Covid-19. Asal mula virus berkembang terjadi di Wuhan, Tiongkok, bulan Desember 2019. Awalnya dianggap sebagai epidemi.
Namun, pada 12 Maret 2020 WHO menetapkan status epidemi menjadi pandemi global. Hingga kini pandemi Covid-19 masih terus berkembang di beberapa negara.

Pandemi Covid-19 memberikan perubahan besar di segala sektor kehidupan.Salah satunya dunia pendidikan.Sebagian besar pemerintah di seluruh dunia menutup sementara lembaga pendidikan dalam upaya untuk mencegah penyebaran pandemi Covid-19 lebih luas.Penutupan nasional ini berdampak pada lebih dari $72 \%$ populasi siswa dunia. Penutupan lokal di beberapa negara lain telah diterapkan hingga berdampak pada jutaan pelajar.

Sekolah Rumah Ramah Anak Sebagai Solusi Pendidikan Jarak Jauh Di Tengah Pandemi Covid-19 
Di Indonesia tak menerapkan itu melainkan mengubah model pembelajaran. Pendidikan yang bermula tatap muka berubah model menjadi jarak jauh.Istilah Pembelajaran Jarak Jauh (PJJ) tak lagi asing di telinga kita saat ini. Transformasi pendidikan yang terjadi secara cepat ini tidak diimbangi dengan penanaman nilai-nilai Pancasila, sehingga dapat menyisakan buih di lautan. Maksudnya, akan banyak lulusan siswa yang pandai namun sedikit siswa yang menerapkan nilai-nilai Pancasila. Tantangan terus menyerang, tetapi pemerintahan tampak bimbang. Nasib penerus bangsa seperti tinggal bayang-bayang.

Sinergi antara siswa, guru, dan orang tua pun belum maksimal. Pendidikan semakin tidak merata. Wakil Sekretaris Jenderal Federasi Serikat Guru Indonesia (FSGI), Satriwan Salim mengaku bahwa metode PJJ yang diterapkan selama pandemi Covid-19 menyebabkan guru maupun siswa tidak maksimal dalam menjalankan proses pembelajaran. Akses teknologi yang minim hingga keterbatasan materi.Kualitas pendidikan pun menurun sangat drastis. Satriwan mengatakan, "Guru terpaksa melakukan pemadatan materi pembelajaran dalam kurikulum yang seharusnya sepuluh bab menjadi lima bab saja. Pengurangan materi dalam kurikulum ini juga diatur dalam Surat Edaran Menteri Pendidikan dan Kebudayaan Nomor 4 Tahun 2020 tentang Pelaksanaan Kebijakan Pendidikan Dalam Masa Darurat Penyebaran Covid-19. Tidak hanya itu, waktu belajar yang didapatkan siswa pun berkurang. Serta, proses pembelajaran yang biasanya ada dialog, diskusi, debat, sekarang menjadi serba terbatas," jelasnya dalam liputan CNN Indonesia.

Dampak PJJ tak hanya pada intelektual siswa tetapi juga psikologisnya. Ketua Komisi Perlindungan Anak, Seto Mulyadi mengatakan salah satu dampak psikologis yang sering sekali dialami anak adalah rasa bosan. Rasa bosan yang terus berkembang akan berdampak pada tingkah laku siswa. Kekerasan juga sangat mungkin terjadi. Serta, menurunnya minat belajar. Apabila hal ini terus terjadi maka Merdeka Belajar yang diterapkan Kemendikbud tak berjalan maksimal. Filosofi Merdeka Belajar yang mengandung makna mendalam, yakni mengajarkan semangat dan cara mendidik anak untuk menjadi manusia yang merdeka batinnya, pikirnya, dan tenaga hanya akan termaknai secara lisan tanpa implementasi nyata. Oleh karena itu, peneliti berupaya untuk memberikan solusi dalam memecahkan masalah pendidikan yang terjadi saat ini. Solusi yang ditawarkan yakni Sekolah Rumah Ramah Anak.

\section{METODOLOGI}

Penelitian ini memakai pendekatan kualitatif. Tujuan penelitian menggunakan pendekatan kualitatif adalah untuk mendeskripsikan makna subjektif yang dikemukakan oleh subjek penelitian terhadap suatu fenomena yang menjadi objek penelitian. Pendekatan kualitatif di sini memakai metode studi literatur, wawancara dan observasi. Studi literatur yakni metode yang mengkomparasikan berbagai sumber tulisan dari media, dokumen, buku, dan lain-lain. Wawancara merupakan metode pengumpulan data yang menunjukkan peneliti sebagai pewawancara mengajukan sejumlah pertanyaan pada partisipan sebagai subjek yang diwawancarai (Johnson \&Christensen, 2004). Sedangkan observasi adalah metode pengumpulan data secara langsung dengan peneliti terjun ke lapangan dan mengondisikan objek penelitian.

Subjek dalam penelitian ini adalah anakanak dan orang tua. Objek penelitian ini yakni proses pembelajaran jarak jauh di masa Pandemi Covid-19. Populasi dalam penelitian ini adalah siswa Sekolah Dasar di Kabupaten Tulungagung dan Blitar. Sampel yang digunakan yakni siswa siswi kelas 1 hingga kelas 6. Observasi dilakukan ke siswa siswi kelas 1 hingga kelas 6 di Kabupaten Blitar. Sedangkan wawancara dilaksanakan di daerah Tulungagung dan Blitar dengan partisipan yang tetap yakni siswa Sekolah Dasar.

Teknik analisis data yang diterapkan dalam penelitian adalah teknik analisis data konvensional. Teknik ini bersifat umum karena dapat digunakan untuk berbagai model penelitian apabila sesuai dengan tujuan penelitian. Ada beberapa teknik analisis data yang bersifat umum antara lain, teknik analisis isi kualitatif dan teknik analisis tematik. Teknik analisis isi kualitatif adalah analisis berdasarkan hubungan kategori-

Sekolah Rumah Ramah Anak Sebagai Solusi Pendidikan Jarak Jauh Di Tengah Pandemi Covid-19 
kategori dengan konsep yang ada dalam penelitian. Sedangkan, teknik analisis tematik merupakan analisis makna berdasarkan tematema yang menonjol dan berhubungan dengan kategori-kategori yang ada dalam tujuan penelitian. Kedua teknik ini digunakan peneliti supaya mendapatkan hasil yang maksimal.

Pada proses analisis data tentu ada prosedurnya. Posedur analisis secara umum ada 6, antara lain peneliti melakukan transkripsi data, melakukan penelaahan secara cermat dan berulang kali terhadap transkrip, membuat segmentasi, membuat tanda atau simbol, mengembangkan sistem kategori, dan membuat master list. Transkripsi data perlu dilakukan karena sumber data masih mentah, biasanya berupa rekaman audio, catatan lapangan, dan lainnya. Kemudian dilanjutkan dengan penelaahan sumber data sesuai dengan tujuan penelitian. Selanjutnya, menggunakan segmentasi. Segmentasi merupakan pembuatan kategori data supaya analisis makna mudah dilakukan. Setelahnya kategori diberi tanda, supaya segmentasi khusus memiliki identitas. Lalu, pengembangan sistem kategori yang telah diberi tanda atau simbol. Pengembangan dapat dilakukan secara deduktif maupun induktif. Tahap terakhir yakni master list. Tahapan yang berisikan definisi dari setiap simbol atau tanda guna membantu peneliti melakukan interpretasi dan pembuatan kesimpulan hasil dari sebuah penelitian.

Demi mendapat hasil yang valid, peneliti berupaya melakukan validitas dua arah terhadap data yang telah terkumpul. Validitas dua arah yakni dengan mengkonfirmasi kembali subjek dan objek penelitian. Setelahnya peneliti pun bisa membuat kesimpulan yang akurat.

\section{HASIL DAN PEMBAHASAN}

Sulianti (2018: 111), menyatakan bahwa Pendidikan nasional merupakan pendidikan yang didasarkan pada Pancasila dan Undang-Undang Dasar RI Tahun 1945 yang berakar pada nilai agama, kebudayaan, nilai-nilai Pancasila dan tanggap terhadap tuntutan perubahan jaman yang tujuannya adalah meningkatkan kualitas manusia Indonesia baik itu sosial, spiritual, dan intelektual, serta professional dalam bidang keilmuannya. Lantas pandemi Covid-19 yang menyebabkan percepatan digitalisasi pendidikan, harus segera diimbangi dengan penguatan moral. Tidak boleh mengikis peran pendidikan yang telah diupayakan sebelumnya. Kurikulum seharusnya mempermudah pemahaman siswa. Serta, memberikan dasar berpikir yang verstehen (mendalam) dan aplikatif.

Peneliti telah melakukan observasi dan wawancara selama tiga minggu untuk melihat perkembangan pendidikan yang terjadi saat ini. Fokusnya pada motivasi belajar, proses pembelajaran, dan pemahaman anak terhadap materi yang diterimanya. Subjekdalam penelitian ini adalah anak-anak dan orang tua. Hasil wawancara dengan lebih dari 10 anak sekolah dasar mengaku bahwa dirinya kesulitan dalam memahami materi. Sedangkan orang tua sulit menjelaskan materi kepada anaknya. Karena materi yang disajikan dalam buku tidak sama dengan pada zamannya. Ditambah lagi dengan tuntutan cakap berteknologi. Analisis ini dapat dibuktikan dari hasil wawancara lisan peneliti kepada subjek penelitian yang dominan menjawab, seperti berikut:

1. Apakah pembelajaran jarak jauh memudahkan proses belajar?

Jawaban anak: Tidak. Saya semakin sulit memahami materi Kak. Waktu istirahat tersisa sedikit karena habis untuk menyelesaikan tugas.

2. Apakah hambatan yang dialami ketika proses pembelajaran jarak jauh sedikit?

Jawaban orang tua: Tidak. Kami tak hanya kesulitan dalam sarana dan prasarana tetapi juga memahamkan anak.

Setiap orang memiliki tingkatan pemahaman yang berbeda-beda tentunya. Berbagai faktor pun mempengaruhinya. Observasi pertama, peneliti akan melihat motivasi belajar anak. Namun, sebelum lebih jauh ke motivasi belajar anak, hal yang mendasari perilaku manusia harus diketahui. Menurut Mc Clellend dan rekan-rekannya, ada tiga hal yang mendasari perilaku manusia, antara lain Need for Achievement (nACH), Need for Affiliation (nAFF) dan Need for Power(nPOW). $\mathrm{nACH}$ merupakan dorongan yang kuat dari individu dalam menyelesaikan tugas dengan hasil yang terbaik atau dorongan untuk berprestasi. nAFF yakni dorongan individu untuk membangun interaksi dengan orang lain menggunakan cara-

Sekolah Rumah Ramah Anak Sebagai Solusi Pendidikan Jarak Jauh Di Tengah Pandemi Covid-19 
cara yang menyenangkan dan juga memelihara rasa afeksi. nPOW adalah dorongan yang kuat dari individu untuk mengontrol orang lain dan mempengaruhi kondisi sosial.

Hasil observasi peneliti, ketiga dorongan tersebut saling mempengaruhi dan berdampak pada motivasi belajar anak. Peneliti melakukan pengondisian lingkungan supaya mendapatkan hasil yang valid. Ia berupaya memberikan apresiasi kepada objek (anak) apabila berhasil menuntaskan tugasnya dengan baik. Di sini ia menerapkan teori the law of effect nya Thorndike. Apabila efek yang didapatkan seseorang baik maka ia akan mengulangi tindakannya. Apabila efek yang didapatkan buruk maka seseorang tidak akan mengulangi tindakannya (Sejati Sugeng, 2012). Hal ini peneliti buktikan dalam observasinya. Anak berhasil menuntaskan tugasnya dan mendapat nilai yang baik. Ketika nilainya baik peneliti memberikan hadiah berupa pembatas buku. Pengaruh terhadap anak adalah meningkatnya keinginan dalam belajar dan tumbuh subur nACH. Namun, ketika anak mendapat nilai yang baik dan tidak diberi apresiasi, keinginan belajarnya menurun hingga tidak mau belajar sama sekali.

Selain teori itu, ia juga menerapkan nAFF dalam proses pendekatan dengan objeknya. Sehingga, nPOW anak meningkat secara drastis. Salah satu upaya anak dalam mengontrol dan mempengaruhi peneliti yakni melarang peneliti pergi darinya dan tetap mengajarinya. Hal ini membuktikan bahwa anak harus diperlakukan dengan halus dan penuh rasa cinta.

Setelah memahami hal-hal yang mempengaruhi motivasi belajar anak, peneliti berupaya mengupas proses pembelajaran yang terjadi ketika PJJ. Orang tua mengaku sulit menerapkan PJJ ini ditengarahi oleh kurangnya wawasan orang tua pada materi yang diberikan guru, kurang cakapnya dalam berteknologi, dan kurangnya rasa sabar. Sehingga komunikasi dua arah sulit terbangun. Materi yang diberikan pun jarang dievaluasi oleh guru. Siswa yang mulanya belum paham semakin tidak paham.

Oleh karena itu, Sekolah Rumah Ramah Anak hadir sebagai solusi dalam memecahkan masalah pendidikan yang terjadi saat ini. Tidak perlu bingung dengan memasukkan anak ke bimbingan belajar. Model sekolah ini hanya mendesain rumah menjadi lebih nyaman untuk proses belajar anak. Berikut proses pembelajaran Sekolah Rumah Ramah Anak:

1. Protokol kesehatan harus diterapkan. Hal ini harus dilakukan supaya memutus rantai penyebaran Covid-19.

2. Sebelum belajar berlangsung, orang tua mengajak anak untuk berdoa. Tahap ini tak kalah penting dari yang lain karena sebuah pertanggungjawaban diri terhadap Sang Pencipta atas tindakannya di dunia. Berdoa merupakan rasa syukur terhadap Tuhan Yang Maha Esa atas segala limpahan rahmat dan rezeki.

3. Kemudian membunyikan Pancasila. Karena Pancasila merupakan dasar bagi bangsa Indonesia dalam menata pendidikan sebagaimana tercantum dalam UU No. 20 tahun 2003 tentang sistem Pendidikan Nasional, yang berbunyi: Pendidikan Nasional berdasarkan Pancasila dan Undang-Undang dasar Negara Indonesia tahun 1945.

4. Memberikan sedikit penjelasan mengapa Pancasila harus dilafalkan. Serta, menanamkan nilai-nilai yang terkandung dalam Pancasila. Sehingga mau tidak mau orang tua harus membaca sejarah bangsa Indonesia. Dengan begitu nilai-nilai Pancasila tetap bisa diimplementasikan di masa pandemi Covid-19. Walaupun guru tak membimbing siswa secara langsung. Dengan kata lain melalui perantara dalam membimbing. Perantaranya yakni orang tua.

5. Selanjutnya penyampaian materi dengan menyesuaikan kondisi anak. Apabila anak tidak lagi memiliki perhatian lebih dengan belajar, orang tua harus bertanya kepada anaknya. Tujuannya untuk mengetahui pikiran anak ketika tidak fokus saat belajar.

6. Pengulangan. Kelima langkah tersebut harus dilakukan secara continue supaya anak tidak lupa dengan materi maupun

Sekolah Rumah Ramah Anak Sebagai Solusi Pendidikan Jarak Jauh Di Tengah Pandemi Covid-19 
nilai-nilai yang disampaikan guru melalui orang tua. Karena kondisi anak ketika pandemi Covid-19 di rumah dan lebih banyak memiliki waktu kosong. Sehingga, rentan untuk lupa. Oleh karena itu, di sela-sela anak bermain, orang tua secara tidak langsung harus juga memasukkan materi sekolah. Tentunya dikemas dengan lebih menyenangkan. Contohnya, mengenalkan berbagai tanaman, hewan, dan alat rumah tangga yang ada di sekitarnya.

Sekolah Rumah Ramah Anak ini orang tua yang memiliki peran utama. Karena orang tua lah yang setiap harinya dekat dengan anaknya. Kunci dari sistem belajarnya yakni memahami karakter anak melalui dasar-dasar perilaku manusia yang telah dipaparkan sebelumnya. Hal ini akan memudahkan orang tua untuk meningkatkan minat belajar anak dan menurunkan rasa malas maupun bosan. Hal lain yang dapat dilakukan yakni dengan menciptakan inovasi belajar yang menarik. Orang tua harus kreatif dalam meningkatkan semangat belajar anak. Apabila orang tua kesulitan dalam mengoperasikan gadget, di sinilah peran Mahasiswa yang ada di daerah. Merdeka Belajar akan optimal apabila seluruh lini bersinergi. Seperti halnya Mahasiswa, Mahasiswa harus mampu melihat kondisi daerahnya dan membantu orang tua siswa dalam mengoperasikan gadget untuk mengakses pendidikan. Penanganan satu anak/siswa akan lebih maksimal apabila guru dengan orang tua bersinergi dengan baik dalam menyampaikan materi.

Dengan melihat sinergi dari berbagai pihak, Sekolah Rumah Ramah Anak ini perlu diterapkan orang tua di Indonesia. Supaya pendidikan dapat merata walaupun pandemi Covid-19 belum sirna. Serta, terciptalah generasi bangsa yang berintelektual, bermoral, dan berbudi pekerti luhur.

\section{SIMPULAN}

Sekolah Rumah Ramah Anak merupakan desain belajar yang membuat anak nyaman dan tidak bosan Karena sedikit mengadaptasi tata cara pembelajaran di sekolah. Hal ini juga dapat mengurangi culture shock siswa dari perubahan sistem belajar konvensional menjadi daring. Adanya aktifitas di rumah ini menghambat pembekuan kreatifitas siswa. Selain itu, melatih daya ingatnya. Serta, mencegah lunturnya nilainilai Pancasila di generasi selanjutnya. Sehingga peneliti merekomendasikan desain pembelajaran yang efektif ini di masa pandemi Covid-19.

\section{REFERENSI}

Abidah., H N Hidaayatullaah., R M Simamora., D Fehabutar.,\& L Mutakinati. (2020). The Impact of Covid-19 to Indonesian Education and Its Relation to the Philosophy of "Merdeka Belajar". Studies in Philosophy of Science and Education (SiPoSE), Volume $1(1), 38-40$.

Chuanmei Donga., C. Simin Caob., \& L. Hui.(2020). Young children's online learning during COVID-19 pandemic: Chinese parents' beliefs and attitudes. Children and Youth Services Review 118 (2020) 105440. www.elsevier.com/locate/childyouth

Fisher, Ronald J. (1982). Social Psychology: An Applied Approach. New York: St. Martin Press.

Hanurawan, F. (2016).Metode Penelitian Kualitatif Untuk Ilmu Psikologi. Jakarta: PT RajaGrafindo Persada.

Johnson, B. \& Christensen, L. (2004).Educational Research: Quantitative, Qualitative, and Mixed Approaches. Boston: Pearson.

Pragholapati, A. (2020). Covid-19 Impact On Students.

Sejati, S. (2012). Psikologi Sosial. Yogyakarta: Teras.

\section{Sitografi:}

CNN Indonesia.(2020). "FSGI Sebut Kualitas Pendidikan Indonesia Turun saat Corona", https://m.cnnindonesia.com/nasional/2020 0502091822-20-499370/fsgi-sebut-kualitaspendidikan-indonesia-turun-saat-corona.

Detik.com. (2020)."Anak Mulai Bosan Pembelajaran Jarak Jauh ini Tips dari Kak Seto", https://m.detik.com/news/berita/d5064132/anak-mulai-bosan-pembelajaranjarak-jauh-ini-tips-dari-kak-seto.

UNESCO.(2020)."Covid-19 Education

Sekolah Rumah Ramah Anak Sebagai Solusi Pendidikan Jarak Jauh Di Tengah Pandemi Covid-19 
Response",

https://en.unesco.org/covid19/educationresp onse.

WHO.(2020). "Indonesia News Novel Coronavirus for

Public", https://www.who.int/indonesia/ news/novel-coronavirus/qa-for-public. 